\title{
Relationship of Appetite, Body Image, and Energy Intake with Body Mass Index in Undergraduate Students in Surakarta
}

\author{
Anita Febrian P Sari ${ }^{1}$, Eti Poncorini Pamungkasari ${ }^{1}$ and Yulia Lanti Retno Dewi ${ }^{2}$ \\ ${ }^{1}$ Masters Program in Nutrition, Universitas Sebelas Maret, Indonesia \\ ${ }^{2}$ Faculty Of Medicine, Universitas Sebelas Maret, Indonesia \\ * corresponding author, e-mail: anitafebrian.permatasari@gmail.com
}

\section{ARTICLE INFO}

Article history

Received 4/30/2021

Revised 6/20/2021

Accepted 8/30/2021

Keywords

Appetite;

Body image;

Intake energy;

$B M I$

\section{ABSTRACT}

Background: Young adults are vulnerable to lifestyle changes that will eventually change their behavior, including health behavior. Behavioral changes during this period can affect nutritional status. Nutritional status is affected by energy intake, influenced by several internal factors such as appetite and body image. This study shows the correlation between appetite, body image, and energy intake with body mass index. Method: This study was conducted with a random sampling method through 120 undergraduate students. Appetite was measured using a visual analog scale. Energy intake was measured using the 24hour food recall method. Statistical analysis used was Spearman's rankBody shape perception was assessed using the Stunkard figure rating scale. Results: Appetite is closely related to energy intake $(p<0.05)$ but not with BMI. Body image correlates with intake energy and BMI. Most obese students $(70.4 \%)$ consider themselves overweight. Energy intake is correlated with BMI $(p<0,001)$. Conclusion: Appetite and body image are related to food intake. Energy intake is correlated with body mass index.

This is an open access article under the CC-BY-SA license.

\section{Introduction}

Nutritional status is an individual's physiological state, resulting from the relationship between nutritional intake and the body's needs and ability to digest, absorb, and use nutrients. Malnutrition is a state of deficiency, excess, or imbalance of energy intake or other nutrients. Nutritional status can be determined in various ways, one of which is using body mass index (BMI). In 20161.9 trillion adults were overweight and 650 million of them were in the obese category. The highest prevalence of obesity is in European, Eastern Mediterranean, and USA countries [1]. In $2018,13.6 \%$ of Indonesia's population was overweight, and $21.8 \%$ was obese. The incidence of overweight in Indonesia has increased from $8.6 \%$ in 2007 to $11.5 \%$ in 2013 and $13.6 \%$ in 2018. The incidence of obesity has also increased from $10.5 \%$ in 2007 to $14.8 \%$ in 2013 and $21.8 \%$ in 2018 [2].

Undergraduate students aged 18-25 experience a transition from adolescence to early adulthood. At that time, they started a new life apart from their parents where they got more freedom, including more freedom to have friends. This transition causes new habits as a form of adaptation to new life. Changes in behavior during this period will usually also impact health, one of which is nutritional status. The number of students in Indonesia in 2015 was around 6.1 million and increased in 2017 to 6.9 million. The number of undergraduate students in 2017 was around 5.5 million. Lotrean research shows that $9.4 \%$ of students are underweight, $16.5 \%$ are overweight, and $3.2 \%$ are obese [3].

Students in the lecture period, besides experiencing changes in diet, also experience changes in physical activity such as increasing screen time and doing the more light physical 
activity than moderate or heavy physical activity [4]. Food intake and physical activity are two factors that are closely related to BMI. Research on students showed a decrease in fruit and vegetable consumption [5]. Spanish students showed that students consume vegetables, sausages, bread, and processed foods more often [6]. On Hungarian university students showed that students' diets rarely consumed vegetables and fruit [7]. In other studies, it appears that healthy students still have bad eating habits such as consuming junk food and soft drinks [8]. From this study, lousy food consumption patterns in students can lead to poor nutritional status. Based on these descriptions, researchers want to determine whether appetite, body image, and food intake are related to gaining BMI in healthy students.

\section{Materials and Method}

A cohort study was conducted on 120 health students in Surakarta, one of the popular cities in Indonesia for undergraduate education, including the undergraduate health program. This research was conducted at three universities in 2019 - 2020. Students who participate are medical, nursing, occupational safety, and health and nutrition students. Selection of subjects using random sampling techniques. In this study, participating students were students in the first year of college because, at this time, students experienced a transition period from adolescence to young adults. The study was conducted for three weeks for every subject. On the first day of the study, weight and height measurements were carried out to determine initial body weight. Research subjects were also asked about how much they slept in one day. Appetite measurement used a visual analog scale. Research subjects filled out the questionnaire after consuming food preceded by fasting for 8 hours. The study subjects marked a line along $100 \mathrm{~mm}$ to describe the feelings felt after he ate food. Research subject appetite was calculated based on the length of the line marked by the research subject. Measurement of appetite was determined once a week before an energy intake assessment.

Body image distortion was assessed by differences in perceived body size and actual body size based on BMI. A zero score indicated an undistortion body image, while a negative or positive score indicated a body image distortion. The numbers on the scale of body image perceptions (perceived or ideal) were also classified according to standard procedures into four groups: 1 and 2 underweight; 3 and 4 normal weight; 5-7 overweight; and 8 and 9 obese shapes. Measurement of energy intake was done by doing a 24-hour recall. Data collection was carried out by professionals and used a food portion book tool, so it is hoped to reduce the possibility of flat slope syndrome and validated household size. Research subjects were interviewed about what they consumed during the past 24 hours. Measurement was done once a week with two days weekdays one day weekends after measuring appetite. The results of the interview were processed using Nutrisurvey software to find out the energy intake in kcal. The calculation results were compared with the nutritional adequacy rate. Participants were divided into three groups: low with energy intake below $70 \%$, adequate with energy intake $70-110 \%$, and Over with above $110 \%$. The data is displayed in the form of a percentage of nutritional adequacy fulfillment. Anthropometric measurements were attained using the following procedure: bodyweight measurement used was a digital weight scale with an accuracy of $0.1 \mathrm{~kg}$. Bodyweight measurements were carried out on the first and 22nd days of data collection. Bodyweight measurements on the first and 22nd days were carried out using the same weight scale. Height was measured by microtoise with a level of accuracy of $0.1 \mathrm{~cm}$. Body mass index (BMI) was calculated by dividing weight by height squared. Participants were divided into four groups: underweight with $\mathrm{BMI}<18.5$, Normal weight with BMI 18.5 - 22.9, overweight with BMI 23 - 24.9, and obese> 25. The univariate data analysis used (minimum, maximum, mean, and standard deviation) and bivariate (Spearman's rank). Relative risk analysis was achieved by comparing the underweight group with the normal group and the obese group with the normal group. Statistical analysis was performed using SPSS software version 24.

\section{Results and Discussion}

\subsection{Results}

Based on Table 1, most students are 18-19 years old (61.7\%). Most of the students weighed 41-60 kg at the beginning of the study, while most had normal weight based on BMI. Their energy intake was around $1500-2000 \mathrm{kcal}(75 \%)$, and in a day, they usually slept 6 to 8 hours (82.5\%). Sleeping habits of less than eight hours per day are associated with improving nutritional status. People with less than eight hours' sleep tend to have a higher energy intake to gain weight. Based on Table 2, the body image and food intake are related to body mass index $(p<0.001)$. The Relative Risk (RR) of body image to Body Mass Index is 4.970 (2.528 - 9.772), which means 
that students who consider themselves thin have a 4.970 greater risk of being underweight than students who consider themselves normal. The Relative Risk (RR) of food intake to the Body Mass Index is $2.241(1.710-2.939)$, which indicates that students who eat more food have a 2.241 times greater risk of being overweight. There is no significant relationship between appetite and body mass index $(p>0.05)$.

Table 1. Characteristics of Research Subjects

\begin{tabular}{|c|c|c|}
\hline Variable & $\mathbf{n}$ & $\%$ \\
\hline \multicolumn{3}{|l|}{ Age (year) } \\
\hline $\begin{array}{l}18-19 \\
20-21\end{array}$ & $\begin{array}{l}74 \\
46\end{array}$ & $\begin{array}{l}61.7 \\
38.3\end{array}$ \\
\hline \multicolumn{3}{|c|}{ Initial Body weight (kg) } \\
\hline $31-40^{\circ}$ & 11 & 9.2 \\
\hline $41-50$ & 40 & 34.2 \\
\hline $51-60$ & 38 & 31.7 \\
\hline $61-70$ & 17 & 14.2 \\
\hline $71-80$ & 4 & 3.3 \\
\hline $81-90$ & 3 & 2.5 \\
\hline $91-100$ & 6 & 5 \\
\hline \multicolumn{3}{|l|}{ Height (cm) } \\
\hline $141-160$ & 95 & 79.2 \\
\hline $161-180$ & 25 & 20.8 \\
\hline \multicolumn{3}{|l|}{ Initial BMI (kg/m²) } \\
\hline$<18.5$ & 26 & 21.7 \\
\hline $18.5-22.9$ & 56 & 46.7 \\
\hline $23.0-24.9$ & 14 & 11.7 \\
\hline$>25$ & 24 & 20 \\
\hline \multicolumn{3}{|c|}{ Energy Intake (Kcal) } \\
\hline$>1,500$ & 18 & 15 \\
\hline $1,500-2,000$ & 90 & 75 \\
\hline$>2,000$ & 12 & 10 \\
\hline \multicolumn{3}{|c|}{ Sleep Duration (hour) } \\
\hline$>6$ & 11 & 9.2 \\
\hline $6-8$ & 99 & 82.5 \\
\hline$>8$ & 10 & 8.3 \\
\hline
\end{tabular}

Table 2. Bivariate Analysis Result

\begin{tabular}{|c|c|c|c|c|c|c|c|}
\hline \multirow[b]{2}{*}{ Variabel } & \multicolumn{5}{|c|}{ Body Mass Index } & \multirow[b]{2}{*}{$\mathbf{p}$} & \multirow[b]{2}{*}{ RR $(95 \%$ Cl) } \\
\hline & $\begin{array}{l}\text { Under } \\
\text { weight }\end{array}$ & Normal & $\begin{array}{c}\text { Over } \\
\text { weight }\end{array}$ & Obesity & Total & & \\
\hline Appetite & & & & & & 0.818 & \\
\hline $\begin{array}{l}\text { Low } \\
\text { Good }\end{array}$ & $\begin{array}{c}9 \\
11\end{array}$ & $\begin{array}{l}30 \\
28\end{array}$ & $\begin{array}{c}10 \\
5\end{array}$ & $\begin{array}{l}15 \\
12\end{array}$ & $\begin{array}{l}64 \\
56\end{array}$ & & \\
\hline Body Image & & & & & & $<0.001$ & \\
\hline Under Weight & 11 & 4 & 1 & 0 & 16 & & $4.970(2.528-9.772)$ \\
\hline Normal & 9 & 52 & 9 & 6 & 76 & & \\
\hline Over Weight & 0 & 2 & 5 & 19 & 26 & & $4.148(2.25-6.554)$ \\
\hline Obesity & 0 & 0 & 0 & 2 & 2 & & \\
\hline Energy Intake & & & & & & $<0.001$ & \\
\hline $\begin{array}{c}\text { Low } \\
\text { Adequate }\end{array}$ & $\begin{array}{c}12 \\
8\end{array}$ & $\begin{array}{l}22 \\
36\end{array}$ & $\begin{array}{l}4 \\
9\end{array}$ & $\begin{array}{c}6 \\
20\end{array}$ & $\begin{array}{l}44 \\
73\end{array}$ & & $1.941(0.895-4.212)$ \\
\hline Over & 0 & 0 & 2 & 1 & 3 & & $2.241(1.710-2.939)$ \\
\hline
\end{tabular}




\subsection{Discussion}

Undergraduate students aged 18-25 experience a transition from adolescence to early adulthood [24]. During this time, many changes occur, such as changes in the friendly environment, living separately from parents, and having more freedom to choose friends or make decisions [25]. These changes impact behavioral patterns that can affect health, one of which is nutritional status.

Energy can be defined as the capacity to do work. Food is the primary source of energy for humans. Energy needs can be interpreted as the energy needed by the human body to grow and develop. A person's energy needs depend on age, gender, body weight, height, and level of physical activity $[9,26]$. If the intake exceeds the need, overweight and obesity can occur $[10]$. Eating behavior is influenced by several factors, including appetite and body image [11]. Appetite is the desire to eat food. For more than 50 years, researchers have attempted to create a possible framework for the relationship between appetite and nutritional status. Appetite is thought to influence food selection and the amount of food consumed [12]. This research subjects who have an appetite below the average of $52.5 \%$. Appetite reflects the motivation to eat and the behavior directed towards consuming food and drink items available in the environment [13]. As seen in the by-product of our study that appetite has a relationship with energy intake.

The results showed that appetite was related to energy intake with an r-value of 0.26. Research in the elderly showed a $25 \%$ decrease in appetite, indicating a $16-20 \%$ decrease in food intake. Appetite influences food selection and the amount of food consumed [12,27-28]. Kessler developed the "food hedonic" theory. This theory is based on the palatability factor is the dominant factor on which to choose the type of food. In simple terms, it can be stated that humans eat for pleasure. The "food hedonic" theory is widely used to explain the causes of obesity. One of the factors suspected to be the cause of obesity is "hedonic eating." The term "hedonic eating" refers to food consumption that is not rooted in the metabolic feedback mechanisms but is related to cognitive, reward, and emotional factors. Hedonic eating is controlled by cortico-limbic areas of the brain, including the accumbens and caudate nuclei (the dopaminergic reward pathway that regulates anticipation and motivation); amygdala and hippocampus (learning); anterior insula (sensory processing); and the orbitofrontal cortex (executive control, decision making, reward value appraisal). Apart from affecting the energy balance, the limbic corticoid area has a role in memory, learning processes, and emotional regulation [14].

Satiety is considered the primary control controlling the amount of food consumed $[29,30]$. Blundell developed a theoretical framework of "Satiety Cascade" 30 years ago to explain the process of satiety. This theoretical framework identifies several factors that control food consumption. Factors that play a role include; 1 ) physiological sensory factors caused by the smell and taste of food, 2) Psychological factors such as cognition, beliefs, and expectations, 3) physiological factors, especially in the stomach area and other parts of the digestive tract. Gastrointestinal peptides such as ghrelin, CCK, PYY, GLP1, and others are appraised to be closely related to appetite control [12]. Appetite is directly related to energy intake, but a person can have appetite variability caused by acute or chronic stress, physical activity, weight loss programs, and pharmacology [13]. Appetite measurements that assess the control of satiety in one episode have not been able to explain the incidence of obesity because of the high variability of appetite in a person, which is a weakness of this study. In the future, appetite measurements can be carried out to measure motivation to eat, food choices, and hedonic processes that can modulate homeostatic systems.

Body image is a picture of our thoughts about the size and shape of bodies and feelings about the characteristics of limbs [15]. Body image is influenced by family and friendship [16]. Differences in body shape image can be caused by adults' active users of social media. Social media such as Instagram or Facebook are an arena for teenagers and young adults to picture the ideal body figure [17]. The use of social media causes someone to compare their body shape with the body shape of friends or the figure of an artist or celebrity. The habit of comparing body shapes can cause a person to want to be thinner to reach their ideal body weight [18]. Perception of body shape can lead to feelings of dissatisfaction. These feelings can lead to eating disorders. Dissatisfaction with the body makes a person undergo a strict diet to lose weight [19]. Research on adolescents also shows that adolescents with a positive image will have better-eating behavior [16]. The results showed that there was no difference in food intake between students. The results can be due to various other factors that affect a person's food intake, such as appetite, stress [20], environmental influences, and social media. Students also tend to consider other factors in choosing food, such as price, activity level, health, and beauty [16]. Body image is related to body mass index, which means that most respondents consider their body shape 
the same as their body mass index. In this study, what should be noted is that most students who have obese nutritional status do not realize it and only consider themselves overweight, and some even consider their weight to be expected, so education about average weight is needed.

The results of this study are in line with several studies that show poor food intake and food habits among nutrition, nursing, and medical students [21-23]. Apart from being influenced by knowledge factors, food intake is also affected by environmental factors such as family eating habits and the availability of food in the environment [11]. Students tend to eat street food and rarely eat fruits and vegetables [6]. A person's eating behavior can be influenced by internal factors such as appetite and body image. Our study shows that energy intake correlates with BMI. Excessive energy intake may occur by a high intake of foods with high energy density. Foods with high energy density contain a large amount of energy per gram of food weight. Consumption of foods with high energy density will increase energy intake and body fat to increase the risk of obesity [8]. According to the Indonesian Nutritional Adequacy Rate, the results showed that only three students had excessive food intake, but 15 people were overweight, and 27 were obese. The low physical activity of students can cause this result. A person's nutritional status is influenced by energy intake and several other factors, such as physical activity, total daily energy expenditure, and the thermic effect of food that can affect energy balance.

\section{Conclusion}

Based on the research results, we can conclude that there is no relationship between appetite and BMI. Obese students tend to consider themselves overweight. Students who consider themselves underweight have a lower energy intake than students who think they are normal, overweight, or obese. Energy intake is also influenced by appetite. Good appetite causes a higher energy intake. The greater the energy intake, the greater risk of becoming obese. Based on the results of this study, we suggest that a nutrition intervention program for malnourished students is carried out. The optimal nutritional status of prospective health workers is expected to be an example and motivation for the community to achieve good nutritional and health status.

\section{Declaration}

Conflicts of Interest: The author has no commercial interests related to this manuscript and there is no conflict of interests for the authors of this manuscript.

\section{References}

1. World Health Organization. Obesity and Overweight [Internet]. 2018 [cited 2018 Oct 2]. Available from: http://www.who.int/news-room/fact-sheets/detail/obesity-and-overweight

2. Younossi, Z. M., Koenig, A. B., Abdelatif, D., Fazel, Y., Henry, L., \& Wymer, M. (2016). Global Epidemiology of Nonalcoholic Fatty Liver Disease-Meta-Analytic Assessment of Prevalence, Incidence, and Outcomes. Hepatology (Baltimore, Md.), 64(1), 73-84. DOI: https://doi.org/10.1002/hep.28431

3. Lotrean LM, Stan O, Lencu C, Laza V. Dietary Patterns, Physical Activity, Body Mass Index, Weight-Related Behaviours and Their Interrelationship Among Romanian University StudentsTrends From 2003 to 2016. Nutricion Hospitalaria. 2018;35(2):375-83. DOI: https://doi.org/10.20960/nh.1296

4. Peterson NE, Sirard JR, Kulbok PA, DeBoer MD, Erickson JM. Sedentary Behavior and Physical Activity of Young Adult University Students. Research in Nursing and Health. 2018;41(1):30-8. DOI: https://doi.org/10.1002/nur.21845

5. Vilaro MJ, Colby SE, Riggsbee K, Zhou W, Byrd-Bredbenner C, Olfert MD, et al. Food Choice Priorities Change Over Time and Predict Dietary Intake at the End of the First Year of College Among Students in the U.S. Nutrients. 2018;10(9):1-13. DOI: https://doi.org/10.3390/nu10091296

6. Porto-Arias JJ, Lorenzo T, Lamas A, Regal P, Cardelle-Cobas A, Cepeda A. Food Patterns and Nutritional Assessment in Galician University Students. Journal of Physiology and Biochemistry. 2018;74(1):119-26. DOI: https://doi.org/10.1007/s13105-017-0582-0

7. Breitenbach Z, Raposa B, Szabó Z, Polyák É, Szűcs Z, Kubányi J, et al. Examination of Hungarian College Students' Eating Habits, Physical Activity and Body Composition. European Journal of Integrative Medicine. 2016;8:13-7. DOI: https://doi.org/10.1016/j.eujim.2016.11.007 
8. Hassanzadazar H, Shokrekhoda A, Aminzare M. Nutritional Behavior of Female Students of School of Paramedical and Health in Zanjan. Journal of Human, Environment, and Health Promotion. 2017;2(4):245-52. DOI: https://doi.org/10.29252/jhehp.2.4.245

9. Mahan LK, Raymond JL. Food \& The Nutrition Care Process. 14th ed. Canada: Elsevier; 2017. 709.

10. Romieu I, Dossus L, Barquera S, Blottière HM, Franks PW, Gunter M, et al. Energy Balance and Obesity: What are the Main Drivers? Cancer Causes and Control. 2017;28(3):247-58. DOI: https://doi.org/10.1007/s10552-017-0869-z

11. Stok FM, Renner B, Clarys P, Lien N, Lakerveld J, Deliens T. Understanding Eating Behavior During the Transition from Adolescence to Young Adulthood: A Literature Review and Perspective on Future Research Directions. Nutrients. 2018;10(6):1-16. DOI: https://doi.org/10.3390/nu10060667

12. Blundell JE. The Contribution of Behavioural Science to Nutrition: Appetite Control. Nutrition Bulletin. 2017;42(3):236-45. DOI: https://doi.org/10.1111/nbu.12279

13. Gibbons C, Hopkins M, Beaulieu K, Oustric P, Blundell JE. Issues in Measuring and Interpreting Human Appetite (Satiety/Satiation) and Its Contribution to Obesity. Current Obesity Reports. 2019 Jun;8(2):77-87. DOI: https://doi.org/10.1007/s13679-019-00340-6

14. Lee PC, Dixon JB. Food for Thought: Reward Mechanisms and Hedonic Overeating in Obesity. Current Obesity Reports. 2017;6(4):353-61. DOI: https://doi.org/10.1007/s13679-017-0280-9

15. Tomas-aragones L, Marron SE. Body Image and Body Dysmorphic Concerns. Acta Derm Venerol. 2016;(2):47-50. DOI: https://doi.org/10.2340/00015555-2368

16. Dewi RC, Wirjatmadi B. Energy Intake, Body Image, Physical Activity and Nutritional Status of Teenagers. Journal of Public Health in Africa. 2019;10(S1). DOI: https://doi.org/10.4081/jphia.2019.1194

17. Sai A, Othman MY, Wan Zaini WFZ, Tan CSY, Mohamad Norzilan NI, Tomojiri D, et al. Factors Affecting Body Image Perceptions of Female College Students in Urban Malaysia. Obesity Medicine. 2018;11:13-9. DOI: https://doi.org/10.1016/j.obmed.2018.06.004

18. Hendrickse J, Arpan LM, Clayton RB, Ridgway JL. Instagram and College Women's Body Image: Investigating the Roles of Appearance-Related Comparisons and Intrasexual Competition. Computers in Human Behavior. 2017;74:92-100. DOI: https://doi.org/10.1016/j.chb.2017.04.027

19. Zarychta K, Chan CKY, Kruk M. Gender-Specific Body Areas Satisfaction and Body Weight Status in Adolescents: Mediating Effects of Physical Activity, Fruit and Vegetable Intake, and Energy-Dense Food Intake. Applied Psychology: Health and Well-Being. 2019;11(1):80-101. DOI: https://doi.org/10.1111/aphw.12145

20. Crooks B, Stamataki NS, Mclaughlin JT. Appetite, the Enteroendocrine System, Gastrointestinal Disease and Obesity. Proceedings of the Nutrition Society. 2020;(December 2019):1-9. DOI: https://doi.org/10.1017/s0029665120006965

21. Bergeron N, Al-saiegh S, Ip EJ. An Analysis of California Pharmacy and Medical Students' Dietary and Lifestyle Practices. American Journal of Pharmaceutical Education. 2017;81(8):5664. DOI: https://doi.org/10.5688/ajpe5956

22. Rahmawati T. Hubungan Asupan Zat Gizi dengan Status Gizi Mahasiswa Gizi Semester 3 Stikes PKU Muhammadiyah Surakarta. Profesi (Profesional Islam) : Media Publikasi Penelitian. 2017;14:49-57. DOI: https://doi.org/10.26576/profesi.148

23. Pratami TJ, Widajanti L, Aruben R. Hubungan Penerapan Prinsip Pedoman Gizi Seimbang Dengan Status Gizi Mahasiswa S1 Departemen IImu Gizi Fakultas Kesehatan Masyarakat Universitas Diponegoro Semarang. Jurnal Kesehatan Masyarakat. 2016;4:561-70. DOI: https://doi.org/10.33757/jik.v1i1.31

24. Layland EK, Exten C, Mallory AB, Williams ND, Fish JN. Suicide Attempt Rates and Associations with Discrimination Are Greatest in Early Adulthood for Sexual Minority Adults Across Diverse Racial and Ethnic Groups. LGBT Heal. 2020;7(8). DOI: https://doi.org/10.1089/lgbt.2020.0142

25. Fletcher JM, Ross SL. Estimating the Effects of Friends on Health Behaviors of Adolescents. Health Econ. 2018;27(10). DOI: https://doi.org/10.1002/hec.3780

26. Hannush MJ. Resilience: The Capacity for Resilience. Markers Psychosoc Matur. 2021;251-7. DOI: 10.1007/978-3-030-74315-4_16

27. Freire RH, Alvarez-Leite JI. Appetite Control: Hormones or Diet Strategies? Curr Opin Clin Nutr Metab Care. 2020;23(5):328-35. DOI: 10.1097/MCO.0000000000000675

28. Dorling J, Broom DR, Burns SF, Clayton DJ, Deighton K, James LJ, et al. Acute and Chronic Effects of Exercise on Appetite, Energy Intake, and Appetite-Related Hormones: The Modulating Effect of Adiposity, Sex, and Habitual Physical Activity. Nutrients. 2018;10(9). DOI: https://doi.org/10.3390/nu10091140 
29. Stribiţcaia E, Evans CEL, Gibbons C, Blundell J, Sarkar A. Food texture influences on satiety: systematic review and meta-analysis. Sci Rep [Internet]. 2020;10(1):1-18. DOI: https://doi.org/10.1038/s41598-020-69504-y

30. Zanchi D, Depoorter A, Egloff L, Haller S, Mählmann L, Lang UE, et al. The impact of gut hormones on the neural circuit of appetite and satiety: A systematic review. Neurosci Biobehav Rev. 2017;80(February):457-75. DOI: https://doi.org/10.1016/j.neubiorev.2017.06.013 